\title{
Quality and Safety Assessment of Water Samples Collected from Wells in Four Emirate Zones of Kebbi State, Nigeria
}

\author{
T. Yahaya ${ }^{1 *}$, O. Ologe², C. Yaro ${ }^{3}$, L. Abdullahi' ${ }^{1}$, H. Abubakar², A. Gazal ${ }^{4}$, J. Abubakar ${ }^{5}$ \\ ${ }^{1}$ Department of Biological Sciences, Federal University Birnin Kebbi, Kebbi State, Nigeria \\ ${ }_{2}^{2}$ Department of Geophysics, Federal University Birnin Kebbi, Kebbi State, Nigeria \\ ${ }^{3}$ Department of Animal and Environmental Biology, University of Uyo, Akwa Ibom State, Nigeria \\ ${ }^{4}$ Department of Geology, Federal University Birnin Kebbi, Kebbi State, Nigeria \\ ${ }^{5}$ Department of Biochemistry and Molecular Biology, Federal University Birnin Kebbi, Kebbi State, Nigeria
}

\section{$P A P E R \quad I N F O$}

\section{Paper history:}

Received 17 October 2021

Accepted in revised form 23 January 2022

\section{Keywords:}

Bacteria

Chronic daily ingestion

Dissolved oxygen

Heavy metals

Lead

\begin{abstract}
$A B S T R A C T$
The increasing prevalence of water-borne diseases necessitates periodic monitoring of domestic and drinking water sources. The current study assessed the safety of well water in the four emirate zones (Gwandu, Yauri, Argungu, and Zuru) of Kebbi State, Nigeria. Using normal procedures, samples of well water were examined for heavy metals, physicochemical characteristics, and microorganisms, and the results were compared to the World Health Organization (WHO) drinking water criteria. The heavy metals' chronic daily ingestion (CDI) and hazard quotient $(H Q)$ were also determined. The results showed that well water in the four emirate zones had normal temperature, biochemical oxygen demand (BOD), dissolved oxygen (DO), total suspended solids (TSS), and zinc (Zn). However, non-permissible concentrations of lead ( $\mathrm{Pb}$ ), iron ( $\mathrm{Fe}$ ), cadmium (Cd), chromium ( $\mathrm{Cr}$ ), and pH (Gwandu and Argungu only) were detected in all the water samples. Except for $\mathrm{Cd}$ and $\mathrm{Cr}$ in children, the $C D I$ and $H Q$ of the heavy metals were normal. The microbiological examinations revealed that the water samples from the four zones had abnormal levels of Bacillus species (bacteria), Escherichia coli (bacteria), Staphylococcus aureus (bacteria), Aspergillus niger (fungi), Mucor racemosa (fungi), and Paecilomyces variotti (fungi). The results obtained suggest that well water in the four zones is not suitable for human consumption unless treated.
\end{abstract}

doi: $10.5829 /$ ijee.2022.13.01.09

\section{INTRODUCTION}

Water is an important component of the environment, which is necessary for life to exist. On Earth, $97.2 \%$ of the water is salty and $2.8 \%$ is fresh water, of which $20 \%$ is groundwater. Groundwater is the best source of fresh water for human use because it has a virtually balanced salt concentration [1]. In comparison to surface water, groundwater is cleaner and pollution-free in an ideal situation [2]. When properly managed, groundwater is cost-effective, safe, consistent in quality and quantity, and available to human.

However, groundwater quality can be compromised by anthropogenic activities such as industrialization, population expansion, unplanned urbanization, and overuse of agrochemicals such as fertilizers and pesticides [3, 4]. The long-term discharge of industrial effluents, domestic sewage, and solid waste pollutes groundwater $[5,6]$. Most of these water contaminants are laden with heavy metals such as mercury $(\mathrm{Hg})$, copper $(\mathrm{Cu})$, chromium $(\mathrm{Cr})$, iron $(\mathrm{Fe})$, lead $(\mathrm{Pb})$, cadmium $(\mathrm{Cd})$, zinc ( $\mathrm{Zn})$, and nickel (Ni), as well as microorganisms like bacteria, viruses, and protozoans [7]. Heavy metals can build up in the human body and deplete antioxidants, producing free radicals and health risks $[8,9]$. Abnormal populations of microorganisms in water can predispose humans to cholera, dysentery, and typhoid fever [10]. According to Dohare et al. [11], water-borne diseases

*Corresponding Author Email: yahaya.tajudeen@fubk.edu.ng (T. Yahaya)

Please cite this article as: T. Yahaya, O. Ologe, C. Yaro, L. Abdullahi, H. Abubakar, A. Gazal, J. Abubakar, 2022. Quality and Safety Assessment of Water Samples Collected from Wells in Four Emirate Zones of Kebbi State, Nigeria, Iranian (Iranica) Journal of Energy and Environment, 13(1), pp.79-86. Doi: 10.5829/ijee.2022.13.01.09 
account for around $80 \%$ of all human diseases. Problems with groundwater quality are much more acute in densely populated and intensively industrialized areas with shallow groundwater tables [6]. Aside from human causes, natural causes may also contaminate groundwater. Groundwater flowing through sedimentary rocks and soils, for example, can absorb a variety of chemical compounds [12].

In Nigeria, particularly those in Kebbi State, many people depend on boreholes and wells for drinking water due to the country's inefficient and inadequate pipe-borne water system [13]. Moreover, practically all of Nigeria's surface water has been severely contaminated by natural sources, humans, and animals. Almost every household in Birnin Kebbi State has a well or borehole for drinking and domestic use. To avoid disease outbreaks and health hazards, continuous monitoring of groundwater throughout the state is required. As a result, this study assessed the safety of well water in Kebbi State's four emirate zones, i.e., Gwandu, Argungu, Yauri, and Zuru zones.

\section{MATERIALS AND METHODS}

\section{Description of the study area}

This study was carried out in Zuru, Yauri, Argungu, and Gwandu emirate zones, Kebbi State, Nigeria (see Figure 1). Kebbi State is in the north-west of Nigeria, between latitudes of $10^{\circ} \mathrm{N}$ and $13^{\circ} \mathrm{N}$ and longitudes of $3^{\circ} \mathrm{E}$ and $6^{\circ}$ E. It borders Sokoto State in the north, Niger State in the south, and Zamfara State in the east. It covers an area of $36,800 \mathrm{~km}^{2}$. The natural vegetation of the state comprises Sudan Savanna in the north and Guinea Savanna in the south [14].

Zuru is the headquarters of the Zuru local government and the Zuru emirate. Zuru can be found at $112^{\circ} 18.4056 \mathrm{~N}$ and $5^{\circ} 54.7968 \mathrm{E}$. Zuru is in the south of Kebbi State, occupying about $9000 \mathrm{~km}^{2}$ of land. Zuru is bordered in the north by Zamfara State and Niger State in the south. The language spoken by the people of Zuru is Dakarkari, and the majority of them engage in intense farming activities. Yauri is the headquarters of Yauri local government and Yauri emirate. Yauri is situated between latitude $10.9925 \mathrm{~N}$ and longitude $4.5212 \mathrm{E}$. Yauri occupies about $3,380 \mathrm{~km}^{2}$. Yauri ethnic groups include the Shangawa, Gungawa, Dukkawa, Kamberi, Hausa, Nupe, Yoruba, and Kanuri. Argungu lies along the Sokoto River. Its coordinates are $12.7333 \mathrm{~N}$ and 4.516667 E. Residents of Argungu are predominantly farmers and are known for the production of tobacco, peanuts, rice, millet, wheat, and sorghum, among others. The city also hosts a yearly international fishing festival. Birnin Kebbi is the capital of Kebbi State and the administrative center of the Gwandu emirate. It lies between $12^{\circ} 27^{\prime} 13^{\prime \prime} \mathrm{N}$ and $4^{\circ} 12^{\prime} 1$ " E. The population of the city was estimated at 125,594 in 2007 . Kebbi is predominantly Hausa and Fulani, with Islam being the predominant religion [15].
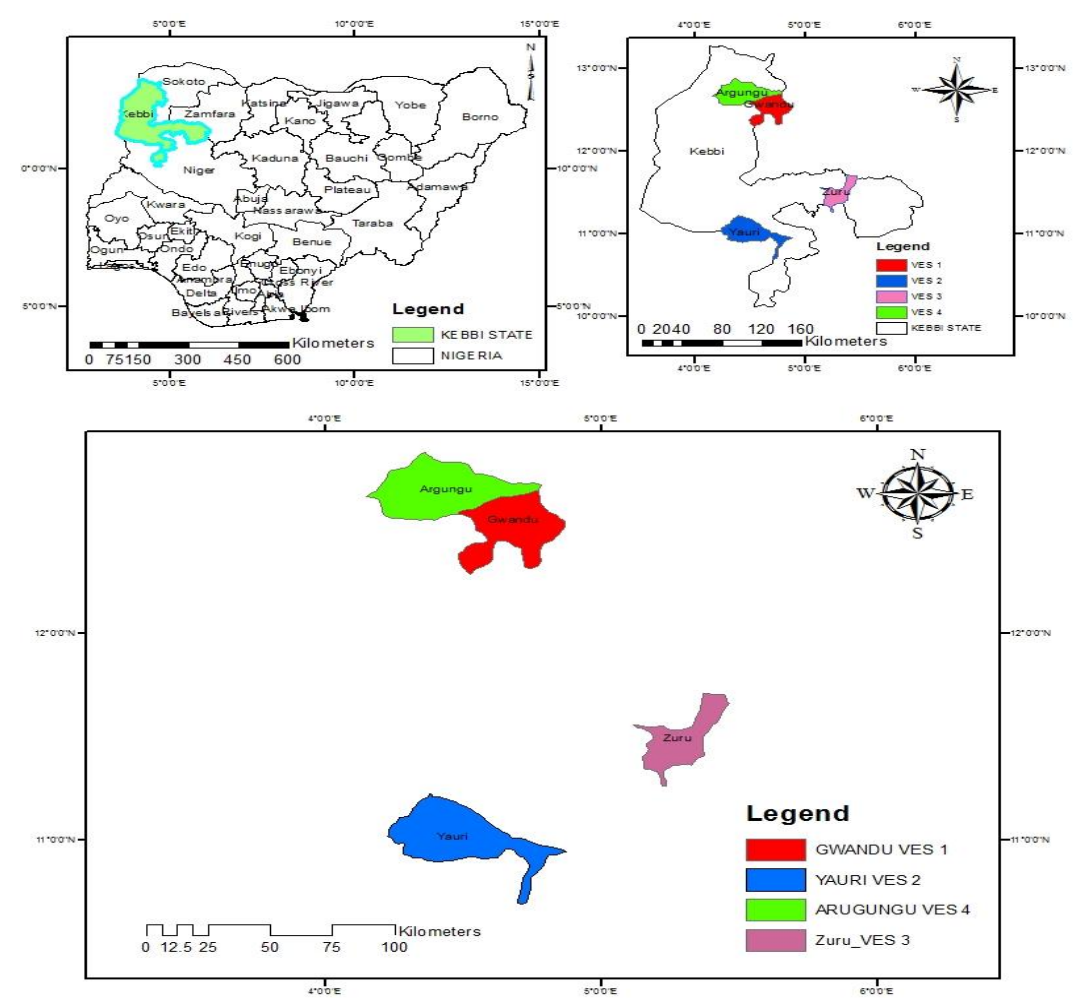

Figure 1. Map of the study area, showing Gwandu, Yauri, Arugungu, and Zuru Emirates 


\section{Sample collection}

Well water samples were collected from Gwandu, Argungu, Yauri, and Zuru emirate zones in Kebbi State in February 2021. The water samples were collected in $1000 \mathrm{~mL}$ pre-sterilized plastic containers, transported to the laboratory in polythene bags, and refrigerated at $\leq 6{ }^{\circ} \mathrm{C}$.

\section{Determination of physicochemical parameters}

The physicochemical parameters of the water samples were determined according to the American Public Health Association's criteria [16]. Temperature and $\mathrm{pH}$ were measured in-situ with a mercury-in-glass thermometer and a digital $\mathrm{pH}$ meter, respectively. In the laboratory, a 5500 Clark DO Sensor and a HM Digital TDS meter (model TDS-4) were used to measure dissolved oxygen (DO) and total suspended solids (TSS), respectively, while a SR2-16 HACH BOD incubator was used to measure biochemical oxygen demand (BOD).

\section{Determination of heavy metals}

A $100 \mathrm{~mL}$ well-mixed water sample was transferred into a beaker and $5 \mathrm{~mL}$ of concentrated $\mathrm{HNO}_{3}$ was added and covered tightly to prevent contamination. The mixture was heated slowly at $95{ }^{\circ} \mathrm{C}$ until it evaporated to about 21 $\mathrm{mL}$. The mixture was poured into a $100 \mathrm{~mL}$ volumetric flask and filled up to the meniscus with distilled water. The solution was allowed to cool, after which it was analyzed for the presence of $\mathrm{Pb}, \mathrm{Fe}, \mathrm{Cd}, \mathrm{Cr}$, and $\mathrm{Zn}$ using a UNICAM atomic absorption spectrometer.

\section{Quality control and assurance}

All the reagents used were made from high-grade chemicals. Each reagent's container was washed in a detergent solution and rinsed thoroughly with water and the reagent. The background contamination of the samples was checked by testing blank samples after every five analyses to ensure the accuracy of the heavy metal analysis. Moreover, each heavy metal was analyzed thrice, and the results were reproducible at a $95 \%$ confidence level. So, the mean value of each heavy metal was used for further analysis.

\section{Health Risk assessment}

The health risk of daily consumption of the water by adults and children was determined from the chronic daily intake $(C D I)$ [17] and hazard quotient $(H Q)$ [18] of heavy metals in the water. These were evaluated using Equations (1) and (2).

$$
C D I=\frac{C w \times I R \times E F \times E D}{B w \times A T}
$$

In the equation above, $C D I$ denotes a consumer's daily ingestion of heavy metals $(\mathrm{mg} / \mathrm{L}), C W$ represents the concentration of heavy metals in water $(\mathrm{mg} / \mathrm{L}), I R$ stands for the ingestion rate, $E F$ represents exposure frequency, $E D$ indicates exposure duration, $B W$ denotes body weight, and $A T$ is the average time. Table 1 shows the standard values for the mentioned parameters.

$$
H Q=\frac{C D I}{R F D}
$$

In Equation (2), $C D I$ stands for the daily ingestion of heavy metals $(\mathrm{mg} / \mathrm{L})$, while $R F D$ represents the reference dose. The standard $R F D$ value for each heavy metal is indicated in Table 2.

\section{Microbiological analysis}

The microbial populations (bacteria, coliforms, and fungi) in the water samples were estimated using the membrane filtering approach described by Brock [19]. A sterile cellulose filter was used to filter $100 \mathrm{~mL}$ of water, and the filter was incubated on a nutrient agar medium for 24 hours at $36^{\circ} \mathrm{C}$. A colony counter was used to count the total number of bacteria that grew on the medium.

The two-step enrichment approach was used to estimate the coliform population in the water. The bacteria-infested filter was placed on a lauryl tryptose broth medium first, then M-Endo media, and incubated at $34{ }^{\circ} \mathrm{C}$ for 3 hours and 22 hours, respectively. The coliforms that grew were then counted.

The nutrient agar was also used to estimate the fungal population, but an antibiotic was added to the medium to prevent bacterial growth [20].

\section{RESULTS}

\section{Physicochemical parameters}

Table 3 shows the physicochemical parameters of well water obtained from Gwandu, Argungu, Yauri, and Zuru

Table 1. Standard values for calculating average daily ingestion of heavy metals

\begin{tabular}{lcc}
\hline Exposure factors & Units & Values \\
\hline Exposure frequency $(E f)$ & Days/Years & 365 \\
Ingestion rate $(I r)$ & L/day & 2 \\
Exposure duration $(E d)$ & Years & 55 \\
Average body weight $(B w t)$ & $\mathrm{Kg}$ & 65 \\
\hline
\end{tabular}

Table 2. Oral reference doses ( $R F D$ ) for $\mathrm{Pb}, \mathrm{Fe}, \mathrm{Cd}, \mathrm{Cr}$, and $\mathrm{Zn}$ in water

\begin{tabular}{lc}
\hline Heavy metal & Values \\
\hline $\mathrm{Pb}$ & 14 \\
$\mathrm{Fe}$ & 700 \\
$\mathrm{Cd}$ & 0.5 \\
$\mathrm{Cr}$ & 3.0 \\
$\mathrm{Zn}$ & 300 \\
\hline
\end{tabular}


Table 3. Physicochemical parameters of well water samples collected in Gwandu, Argungu, Yauri, and Zuru Emirates in Kebbi State, Nigeria

\begin{tabular}{|c|c|c|c|c|c|}
\hline \multirow{2}{*}{ Parameters } & \multicolumn{4}{|c|}{ Emirate } & \multirow{2}{*}{- Limit } \\
\hline & Gwandu & Argungu & Yauri & Zuru & \\
\hline $\mathrm{pH}$ & $5.95 \pm 0.15$ & $4.89 \pm 0.31$ & $7.18 \pm 0.04$ & $6.55 \pm 0.17$ & $6.5-8.5$ \\
\hline Temp $\left({ }^{\circ} \mathrm{C}\right)$ & $24.66 \pm 0.36$ & $24.50 \pm 0.43$ & $24.12 \pm 1.04$ & $24.0 \pm 1.09$ & - \\
\hline DO & $7.13 \pm 0.05$ & $7.27 \pm 0.09$ & $7.09 \pm 0.13$ & $7.21 \pm 0.08$ & $7-14$ \\
\hline BOD & 50 & 8.79 & 1.8 & 30.77 & 60 \\
\hline TSS & 360 & 140 & 460 & 100 & NA \\
\hline
\end{tabular}

Values were expressed as mean \pm SD and $\mathrm{mg} / \mathrm{L} ; \mathrm{NA}=$ Not Available; $\mathrm{DO}=$ Dissolved Oxygen; $\mathrm{BOD}=$ Biochemical Oxygen Demand; TSS= Total Suspended Solid

emirates. The temperature, DO, BOD, and TSS of all the water samples were within the range of World Health Organization (WHO) acceptable limits. However, the $\mathrm{pH}$ of Gwandu and Argungu were above the acceptable limits.

Concentration of heavy metals in the water samples Table 4 shows the levels of heavy metals in the well water obtained from Gwandu, Argungu, Yauri, and Zuru emirates. All the water samples had abnormal levels of all the heavy metals, with the exception of $\mathrm{Zn}$.

\section{Health risk assessment of daily ingestion of the water} The CDI of heavy metals per person for adults and children in Birnin Kebbi, Argungu, Yauri and Zuru are presented in Tables 5 and 6, respectively. The $C D I$ of all the heavy metals was normal in adults. However, in children, the $C D I$ of $\mathrm{Cd}$ and $\mathrm{Cr}$ was higher than the recommended limit, while other heavy metals were within the recommended limits.

Table 4. Levels of heavy metals in well water samples collected in Gwandu, Argungu, Yauri, and Zuru Emirates in Kebbi State, Nigeria

\begin{tabular}{lccccc}
\hline Emirate & $\mathbf{P b}$ & $\mathbf{C d}$ & $\mathbf{C r}$ & $\mathbf{Z n}$ & $\mathbf{F e}$ \\
\hline \multirow{2}{*}{ Gwandu } & $1.315 \pm$ & $0.959 \pm$ & $4.507 \pm$ & $1.284 \pm$ & $1.358 \pm$ \\
& 0.00200 & 0.00100 & 0.00100 & 0.00100 & 0.00100 \\
& & & & & \\
Argungu & $0.937 \pm$ & $0.965 \pm$ & $4.552 \pm$ & $1.295 \pm$ & $1.176 \pm$ \\
& 0.00200 & 0.00100 & 0.00200 & 0.00100 & 0.00200 \\
Yauri & $0.886 \pm$ & $0.959 \pm$ & $4.650 \pm$ & $1.277 \pm$ & $0.940 \pm$ \\
& 0.00100 & 0.00100 & 0.00100 & 0.00100 & 0.00100 \\
Zuru & $1.315 \pm$ & $1.001 \pm$ & $4.800 \pm$ & $1.333 \pm$ & $1.303 \pm$ \\
& 0.00400 & 0.00100 & 0.00200 & 0.00153 & 0.00200 \\
Limit & $\leq 0.01$ & $\leq 0.003$ & $\leq 0.05$ & $\leq 3.00$ & $\leq 0.3$ \\
{$[21]$} & & & & & \\
\hline Values Wer & & & & &
\end{tabular}

Values were expressed as mean \pm SD and $\mathrm{mg} / \mathrm{L}$
Table 5. Chronic daily ingestion of heavy metals per person for adults in Gwandu, Argungu, Yauri, and Zuru Emirates in Kebbi State, Nigeria

\begin{tabular}{lccccc}
\hline Emirate & Pb & Cd & Cr & Zn & Fe \\
\hline Gwandu & 0.0405 & 0.0295 & 0.139 & 0.0395 & 0.0418 \\
Argungu & 0.0288 & 0.0297 & 0.140 & 0.0398 & 0.0362 \\
Yauri & 0.0273 & 0.0295 & 0.143 & 0.0393 & 0.0289 \\
Zuru & 0.0405 & 0.0308 & 0.148 & 0.0410 & 0.0401 \\
RDI & 0.21 & 0.06 & 0.20 & 3.0 & 0.30 \\
\hline
\end{tabular}

Values expressed as mg/day; RIDI: recommended daily intake

Table 6. Chronic daily ingestion of heavy metals per person for children in Gwandu, Argungu, Yauri, and Zuru Emirates in Kebbi State, Nigeria

\begin{tabular}{lccccc}
\hline Emirate & $\mathbf{P b}$ & $\mathbf{C d}$ & $\mathbf{C r}$ & $\mathbf{Z n}$ & $\mathbf{F e}$ \\
\hline Gwandu & 0.088 & 0.064 & 0.30 & 0.086 & 0.091 \\
Argungu & 0.062 & 0.064 & 0.31 & 0.086 & 0.078 \\
Yauri & 0.059 & 0.064 & 0.31 & 0.085 & 0.063 \\
Zuru & 0.088 & 0.067 & 0.32 & 0.089 & 0.087 \\
RDI & 0.21 & 0.06 & 0.20 & 3.0 & 0.3
\end{tabular}

Values expressed as mg/day; RDI: recommended daily intake

The $H Q$ of the heavy metals for both adults and children is shown in Tables 7 and 8, in which the $H Q$ of the heavy metals in all the water samples was less than 1 , for both adults and children.

Table 7. Hazard quotient of heavy metals via ingestion by adults in Gwandu, Argungu, Yauri, and Zuru Emirates in Kebbi State, Nigeria

\begin{tabular}{lccccc}
\hline Emirate & $\mathbf{P b}$ & $\mathbf{C d}$ & $\mathbf{C r}$ & $\mathbf{Z n}$ & $\mathbf{F e}$ \\
\hline Gwandu & 0.00289 & 0.059 & 0.0463 & 0.0001316 & 0.000059 \\
Argungu & 0.00206 & 0.0594 & 0.0467 & 0.0001326 & 0.000051 \\
Yauri & 0.00195 & 0.059 & 0.0477 & 0.000131 & 0.000041 \\
Zuru & 0.00289 & 0.0616 & 0.0493 & 0.000136 & 0.000057 \\
\hline
\end{tabular}

Table 8. Hazard quotient of heavy metals via ingestion by children in Gwandu, Argungu, Yauri, and Zuru Emirates in Kebbi State, Nigeria

\begin{tabular}{lccccc}
\hline Zone & Pb & Cd & Cr & Zn & Fe \\
\hline Gwandu & 0.0063 & 0.128 & 0.10 & 0.0029 & 0.00013 \\
Argungu & 0.0044 & 0.128 & 0.103 & 0.0029 & 0.00011 \\
Yauri & 0.0042 & 0.128 & 0.103 & 0.0028 & 0.00009 \\
Zuru & 0.0063 & 0.134 & 0.12 & 0.003 & 0.00012 \\
\hline
\end{tabular}




\section{Loads and microorganism species in the water samples}

In Table 9, the loads and species of total bacteria, fungi, and coliforms found in the water samples are presented. The water samples had abnormal counts of total bacteria, total fungi, and coliform bacteria, except in Yauri, where coliform was not detected. Total bacteria had the highest count of all the microorganisms detected, with $29.5 \times 10^{6}$ in Yauri, $28.5 \times 10^{6}$ in Zuru, and $4.3 \times 10^{6}$ in Argungu. The lowest total bacteria count was observed in Gwandu, which was too few to count. The biochemical tests of the isolates revealed that all the water samples contained Bacillus species (bacteria), Staphylococcus aureus (bacteria), Escherichia coli (bacteria), Mucor racemosa (fungi), Paecilomyces variotti (fungi), and Aspergillus niger (fungi).

\section{DISCUSSION}

This study evaluated the safety of well water in Gwandu, Argungu, Yauri, and Zuru Emirate zones in Kebbi State, Nigeria. Table 3 shows that the physicochemical parameters of the water samples from the four zones were normal, except for the $\mathrm{pH}$ of Gwandu and Argungu, which are slightly acidic. This result is consistent with most of the studies that analyzed the physicochemical parameters of groundwater in the state. Notably, Elinge et

Table 9. Levels and species of microorganisms isolated from well water samples collected in Gwandu, Argungu, Yauri, and Zuru Emirates in Kebbi State, Nigeria

\begin{tabular}{|c|c|c|c|c|c|}
\hline \multirow{2}{*}{ Zone } & \multirow{2}{*}{$\frac{\text { TBC }}{10^{6}}$} & \multirow{2}{*}{ TFC } & \multicolumn{2}{|c|}{ TCC } & \multirow{2}{*}{ Species isolated } \\
\hline & & & MPN & EMB & \\
\hline Gwandu & TFTC & 9.4 & 79 & 26 & $\begin{array}{l}\text { Aspergillus niger, } \\
\text { Escherichia coli, } \\
\text { Bacilluss sp, } \\
\text { Candida albicans }\end{array}$ \\
\hline Argungu & 4.3 & 4.1 & 17 & 19 & $\begin{array}{l}\text { Aspergillus niger, } \\
\text { Paecilomyces variotti, } \\
\text { Staphylococcus } \\
\text { aureus, Bacilluss sp, } \\
\text { Escherichia coli }\end{array}$ \\
\hline Yauri & 29.7 & 4.5 & 6 & ND & $\begin{array}{l}\text { Aspergillus niger, } \\
\text { Staphylococcus } \\
\text { aureus, Bacilluss sp }\end{array}$ \\
\hline Zuru & 28.5 & TNTC & 33 & 94 & $\begin{array}{l}\text { Aspergillus niger, } \\
\text { Mucor racemosa, } \\
\text { Staphylococcus } \\
\text { aureus, Bacilluss sp, } \\
\text { Escherichia coli }\end{array}$ \\
\hline Limit [22] & $\begin{array}{c}\leq 100 \\
\mathrm{CFU} / \mathrm{mL}\end{array}$ & $\begin{array}{c}\leq 50 \\
\mathrm{CFU} / \mathrm{mL}\end{array}$ & 0 & 0 & \\
\hline \multicolumn{6}{|c|}{$\begin{array}{l}\text { TBC }=\text { Total Bacteria Count; } \mathrm{TFC}=\text { Total Fungi Count; } \mathrm{TCC}=\text { Total } \\
\text { Coliform Count; EMB }=\text { Eosin Methylene Blue MPN= Most Probable } \\
\text { Number; TFTC }=\text { Too Few to Count; TNTC }=\text { Too Numerous to Count; } \\
\text { ND: Not Detected }\end{array}$} \\
\hline
\end{tabular}

al. [23] and Wali et al. [24] reported a decrease in the $\mathrm{pH}$ of groundwater in Birnin Kebbi and Bunza in Kebbi State. Aliyu et al. [25] also observed normal physicochemical parameters in well water obtained from Argungu in Kebbi State. The reduced $\mathrm{pH}$ of well water from Gwandu and Argungu may not pose a serious health risk to consumers because $\mathrm{pH}$ has no direct adverse effects on health [26]. However, in sensitive individuals, gastrointestinal irritation as well as redness and irritation of the eyes may occur [27].

The heavy metal analysis shows that the water samples from the four zones contained abnormal concentrations of $\mathrm{Cd}, \mathrm{Cr}, \mathrm{Pb}$, and $\mathrm{Fe}$ (Table 2). Elinge et al. [23] found abnormal levels of some heavy metals in well water samples obtained from Bunza, Kebbi State. Shabanda et al. [28] detected abnormal quantities of several heavy metals in boreholes and wells in Aliero, Kebbi State. These findings show that well water in Kebbi State may be grossly contaminated with heavy metals and so may not be suitable for consumption unless treated. A cadmium overdose may cause diarrhea, lung and kidney damage, vomiting, stomach irritation, and bone weakness [29]. Lead exposure may cause cancer, vitamin D deficiency, high blood pressure, brain damage, infertility, and mental impairment in children [30]. An erythropoietin effect, such as a swollen goiter, can be induced by excessive chromium ions in water [31]. Water with high levels of iron can cause fatigue, heart and liver disease, and diabetes mellitus [32].

The $C D I$ of the individual heavy metals by adults was within the permissible limits, and the same goes for children, except for $\mathrm{Cd}$ and $\mathrm{Cr}$ (Tables 5 and 6). This shows that children could be at an increased risk of $\mathrm{Cd}$ and $\mathrm{Cr}$ toxicities. However, the $H Q$ of the individual heavy metals for adults and children is less than one (Tables 7 and 8), which is the upper limit at which a substance can be considered non-toxic. This suggests that the water may not pose a serious health risk to adults and children. But in strict environmental terms, there is no safe level for heavy metals. Furthermore, heavy metals may combine additively and increase the risk of daily consumption of a substance.

Table 9 reveals that the well water samples from the four zones had abnormal bacteria, coliform, and fungal counts, which again proved that the water may predispose consumers to health hazards. Bacillus species (bacteria) were detected in the water, which can induce toxins in humans [33]. The presence of Escherichia coli (coliform) indicates that the water has been contaminated by fecal matter and may cause diarrhea [34]. Staphylococcus aureus (bacteria) seen in the water can cause boils, furuncles, cellulitis, blood infections, and pneumonia [35]. Aspergillus niger (fungus) was also found in the water, which may cause allergic reactions and opportunistic invasive infections [36]. Mucor racemosa (fungus) observed in the water can cause vascular invasion, resulting in thrombosis, infarction, and tissue 
necrosis [37]. The water also contained Paecilomyces variotti (fungus), which often causes peritonitis, cutaneous and disseminated infections [38]. Almost all previous microbiological studies of groundwater in Kebbi State reported the presence of heavy microbial populations. Importantly, Shemishere et al. [39] detected abnormal levels of some microorganisms in borehole water in Birnin Kebbi and Kalgo. Ola-Buraimo et al. [40] reported abnormal populations of some microorganisms in well water in several parts of Kebbi State. Elinge et al. [41] reported non-permissible levels of certain microbial species in borehole water from Aliero, Kebbi State. Bashir et al. [42] detected abnormal levels of bacteria and coliform in Sokoto, a neighboring state.

\section{CONCLUSION}

It can be concluded from the results that well water in Kebbi State is grossly contaminated. Non-permissible levels of $\mathrm{Pb}, \mathrm{Fe}, \mathrm{Cd}$, and $\mathrm{Cr}$ were detected in well water samples from all the four emirate zones (Gwandu, Argungu, Zuru, and Yauri) of the state. In addition, the well water from Gwandu and Argungu zones had a reduced $\mathrm{pH}$ and was thus slightly acidic. The $C D I$ of $\mathrm{Cd}$ and $\mathrm{Cr}$ by children in all the four zones was above the normal limit, suggesting that children might be at an increased risk of $\mathrm{Cd}$ and $\mathrm{Cr}$ toxicities. The water samples also contained abnormal levels of bacteria, fungi, and coliform species, which further proved the non-suitability of the water for consumption.

\section{RECOMMENDATIONS}

The following are suggestions based on the current study's findings:

- Residents should consider water purification before consuming it.

- Members of the communities should engage in environmental sanitation.

- There is an urgent need for public enlightenment in the state regarding the risks of consuming contaminated water.

- The wells should be capped and the well casings should be water tight.

- Governments should ensure clean and safe water in the state.

- Periodic monitoring of water quality in the state is advised.

\section{ACKNOWLEDGEMENT}

This research was conducted in the Microbiology Laboratory at Federal University Birnin Kebbi, Nigeria, and the Chemistry Laboratory at Usmanu Danfodiyo University, Sokoto, Nigeria.

\section{CONFLICT OF INTEREST}

The authors declare that they hold no competing interests.

\section{REFERENCES}

1. Kolekar, S.S., 2017. Physico-chemical analysis of ground water quality parameters-A Review. Journal of Chemical and Pharmaceutical Sciences, 10(1), pp.376-378. https://www.jchps.com/issues/Volume\%2010_Issue\%201/770160916.pdf

2. Patil, V.T., and Patil, P.R., 2010. Physicochemical Analysis of Selected Groundwater Samples of Amalner Town inJalgaon District, Maharashtra, India. E-Journal of Chemistry, 7(1), pp.111-116. Doi: 10.1155/2010/820796

3. Joarder, M.A.M., Raihan, F., Alam, J.B., and Hasanuzzaman, S., 2008. Regression analysis of ground water quality data of Sunamganj District, Bangladesh. International Journal of Environmental Research (IJER), 2(3), pp.291-296. http://www.bioline.org.br/request?er08039

4. Tesfalem, N., Tesfamariam, A., Okbaslasie, A., and Tesfay, K., 2019. Physico-chemical Analysis of Groundwater Around MaiBela, Asmara, Eritrea. American Academic Scientific Research Journal for Engineering, Technology, and Sciences, 57(1), pp.161-186.

https://www.asrjetsjournal.org/index.php/American_Scientific_J ournal/article/view/4928

5. Easa, A., and Abou-Rayan, A., 2010. Domestic wastewater effect on the pollution of the groundwater in rural areas in Egypt. aquatic,

3(4). https://beng.stafpu.bu.edu.eg/Civil\%20Engineering/3609/publica tions/Alnnos\%20ali\%20aisa\%20higazy_Ground $\% 20$ water\%20po lllution.pdf

6. Sasakova, N., Gregova, G., Takacova, D., Mojzisova, J., Papajova, I., Venglovsky, J., Szaboova, T., and Kovacova, S., 2018. Pollution of Surface and Ground Water by Sources Related to Agricultural Activities. Frontiers in Sustainable Food Systems, 2. Doi: 10.3389/fsufs.2018.00042

7. Kass, A., Gavrieli, I., Yechieli, Y., Vengosh, A., and Starinsky, A., 2005. The impact of freshwater and wastewater irrigation on the chemistry of shallow groundwater: a case study from the Israeli Coastal Aquifer. Journal of Hydrology, 300(1-4), pp.314-331. Doi: 10.1016/j.jhydrol.2004.06.013

8. Yahaya, T., Okpuzor, J., and Esther, O.O., 2012. Investigation of Cytotoxicity and Mutagenicity of Cement Dust Using Allium cepa Test. Research Journal of Mutagenesis, 2(1), pp.10-18. Doi: 10.3923/rjmutag.2012.10.18

9. Yahaya, T.O., Oladele, E.O., Chibs, B., Abdulazeez, A., Nnochiri, K., Stephen, A.O., Ahmed, H., and Daniel, A., 2020. Level and Health Risk Evaluation of Heavy Metals and Microorganisms in Urban Soils of Lagos, Southwest Nigeria. Algerian Journal of Biosceinces, 1(02), pp.51-60. Doi: http://dx.doi.org/10.5281/zenodo.4394091

10. Hannan, A., Shan, S., and Arshad, U.M., 2010. Bacteriological analysis of drinking water from 100 families of Lahore by membrane filtration technique and chromagar. Biomedica, 26(Jul.Dec.), pp.152-156. http://thebiomedicapk.com/articles/222.pdf

11. Dohare, D., Deshpande, S., and Kotiya, A., 2014. Analysis of ground water quality parameters: a Review. Research Journal of Engineering Sciences ISSN, 2278, pp.9472. 
http://www.isca.in/IJES/Archive/v3/i5/3.ISCA-RJEngS-201424.pdf

12. Ghrefat, H., Nazzal, Y., Batayneh, A., Zumlot, T., Zaman, H., Elawadi, E., Laboun, A., Mogren, S., and Qaisy, S., 2014. Geochemical assessment of groundwater contamination with special emphasizes on fluoride, a case study from Midyan Basin, northwestern Saudi Arabia. Environmental Earth Sciences, 71(4), pp.1495-1505. Doi: 10.1007/s12665-013-2554-1

13. Yahaya, T.O., Oladele, E.O., Fatodu, I.A., Abdulazeez, A., and Yeldu, Y.I., 2020. The concentration and health risk assessment of heavy metals and microorganisms in the groundwater of Lagos, Southwest Nigeria. Journal of Advances in Environmental Health Research, 8(3), pp.234-242. Doi 10.22102/jaehr.2020.245629.1183

14. Yahaya, T., Aliero, A.A., Oladele, E., CD, O., Nathaniel, J., and MZ, A., 2021. Concentration and Cytogenotoxicity of Heavy Metals and Microorganisms in Labana Rice Mills Wastewater Birnin Kebbi, Northwestern Nigeria. Nigerian Research Journal of Engineering and Environmental Sciences, 6(1), pp.216-225. Doi: http://doi.org/10.5281/zenodo.5048285

15. Bello, M.N., and Jeb, D.N., 2014. Analysis of flood risk inundation hazard in Birnin Kebbi town, Kebbi State, Nigeria. International Journal of Geomatics and Geosciences, 5(1), pp.119-131.

http://www.ipublishing.co.in/jggsarticles/volfive/EIJGGS5011.p df

16. American Public Health Association, 2012. Standard Methods for the Examination of Water and Wastewater, 22nd edition. In: Washington, D.C. Washington, D.C.

17. Muhammad, S., Shah, M.T., and Khan, S., 2011. Health risk assessment of heavy metals and their source apportionment in drinking water of Kohistan region, northern Pakistan Microchemical Journal, 98(2), pp.334-343. Doi: 10.1016/j.microc.2011.03.003

18. United States Environmental Protection Agency, 1999. Guidance for performing aggregate exposure and risk assessments," Office of Pesticide Programs. In: Washington, D.C.

19. Brock, T.D., 1983. Membrane filtration: A user's guide and reference manual. In: Madison, WI: Science Tech, Inc.

20. Babič, M., Gunde-Cimerman, N., Vargha, M., Tischner, Z., Magyar, D., Veríssimo, C., Sabino, R., Viegas, C., Meyer, W., an Brandão, J., 2017. Fungal Contaminants in Drinking Water Regulation? A Tale of Ecology, Exposure, Purification and Clinical Relevance. International Journal of Environmental Research and Public Health, 14(6), pp.636. Doi: 10.3390/ijerph14060636

21. World Health Organization, 2017. Guidelines for Drinking-Water quality: First Addendum to the Fourth Edition, Geneva, Switzerland.

22. World Health Organization, 2008. Guidelines for Drinking waterQuality: Incorporating the first and second addenda volume1 Recommendations, Geneva, Switzerland.

23. Elinge, C., 2015. Physico-Chemical and Heavy Metal Analyses of Some Ground Water in Bunza, North Western, Nigeria. American Journal of Applied Chemistry, 3(4), pp.153. Doi: 10.11648/j.ajac.20150304.12

24. Wali, S.U., Umar, K.J., Abubakar, S.D., Ifabiyi, I.P., Dankani, I.M., Shera, I.M., and Yauri, S.G., 2019. Hydrochemical characterization of shallow and deep groundwater in Basement Complex areas of southern Kebbi State, Sokoto Basin, Nigeria Applied Water Science, 9(8), pp.169. Doi: 10.1007/s13201-019$1042-5$

25. Aliyu, A.K., Birnin-Yauri, U.A., Umar, K.J., Isa, S.A., and Nasiru, M.K., 2018. Assessment of some physicochemical parameters and heavy metals in groundwater obtained from sandy area of Argungu Emirate, Kebbi State, Nigeria. Continental Journal of Applied Science, 13(1), pp.1-15. Doi: 10.5281/zenodo.1193935
26. Parvez, N., and Pritul, A.S., 2018. Analysis of Ground Water Quality: A Case Study in the Savar (Akrain) Area. Journal of Water Resources and Pollution Studies, 3(3), pp.67-75. Doi: 10.5281/zenodo. 1626349

27. World Health Organization, 2006. Guidelines for drinking-water quality: Health criteria and other supporting information', 2nd ed. Vol. 2, Geneva.

28. Shabanda, I., Kilgori, S., Umar, S., and Aminu, M., 2014. Selected Trace Heavy Metals Concentrations in Well and Borehole Water in Aliero Metropolis. International Research Journal of Pure and Applied Chemistry, 4(6), pp.880-886. Doi: 10.9734/IRJPAC/2014/11640

29. Rahimzadeh, M.R., Rahimzadeh, M.R., Kazemi, S., and Moghadamnia, A., 2017. Cadmium toxicity and treatment: An update. Caspian journal of internal medicine, 8(3), pp.135-145. Doi: https://doi.org/10.22088/cjim.8.3.135

30. Nigerian Standard for Drinking Water Quality (NSDWQ), 2007. Nigerian Industrial Standard NIS 554 Standard Organization of Nigeria.

31. Adeyemi, A.A., and Ojekunle, Z.O., 2021. Concentrations and health risk assessment of industrial heavy metals pollution in groundwater in Ogun state, Nigeria. Scientific African, 11, pp.e00666. Doi: 10.1016/j.sciaf.2020.e00666

32. Ekere, N.R., Hedioha, J.N., Eze, I.S., and Agbazue, V.E., 2014. Health risk assessment in relation to heavy metals in water sources in rural regions of South East Nigeria. International Journal of Physical Sciences, 9(6), pp.109-116. Doi: 10.5897/IJPS2014.4125

33. Popoff, M., 2011. Multifaceted interactions of bacterial toxins with the gastrointestinal mucosa. Future Microbiology, 6(7), pp.763-797. Doi: 10.2217/fmb.11.58

34. Kingdom, T., Zige, D.V., and Anesakeme, D., 2018. Assessing the hygienic status of processed fresh water clam (Galatea paradoxa) in Yenagoa Metropolis, Bayelsa State, Niger Delta, Nigeria. American Journal of Food Science and Technology, 6(5), pp.219222. Doi: 10.12691/ajfst-6-5-5

35. Minnesota Department of Health, 2019. About Staphylococcus aureus", Minnesota Department of Health Fact Sheet.

36. de Hoog, G.S., Guarro, J., Díaz, J.G., Ahmed, S.A., Al Hatmi, A.M.S., Figueras, M.J., and Vitale, R.G., 2021. Atlas of Clinical Fungi: The Ultimate Benchtool for Diagnostics. Introductions, Lower Fungi, Basidiomycetes, Yeasts, Filamentous Ascomycetes AB. Part A. Foundation Atlas of Clinical Fungi. Doi: $10.1007 / \mathrm{s} 101230100009$

37. Augustina Egbuta, M., Mwanza, M., and Oluranti Babalola, O., 2016. A Review of the Ubiquity of Ascomycetes Filamentous Fungi in Relation to Their Economic and Medical Importance. Advances in Microbiology, 06(14), pp.1140-1158. Doi: 10.4236/aim.2016.614103

38. Moreira, D., Oliveira, M., and Borba, C., 2018. Human Pathogenic Paecilomyces from Food. Microorganisms, 6(3), pp.64. Doi: 10.3390/microorganisms6030064

39. Shemishere, U., Yahaya, T., Anyebe, D., and Bello, A., 2019. Heavy Metal and Microbial Contents of Borehole Water in Birnin Kebbi and Kalgo Metropolis, Kebbi State, Nigeria. Savanna Journal of Basic and Applied Sciences, 1(2), pp.261-268. https://www.sjbas.com.ng/journal/103748261-268.pdf

40. Ola-Buraimo, A.O., Ologe, O., and Benemaikwu, O.D., 2018. Field Geology and Microbiological Investigation of Borehole, Public Tap Water and Hand-Dug Wells in Some Parts of Birnin Kebbi, Nigeria. Nigerian Journal of Scientific Research, 17(3), pp.229-240. https://journal.abu.edu.ng/index.php/njsr

41. Elinge, C.M., Yusuf, H., Jude, N., Peni, I.J., and Owusu, K.B., 2010. Physicochemical and Bacteriological Profiles of Borehole Water from Aliero Community of Kebbi State, Nigeria. International Journal of Tropical Agriculture and Food Systems, 
4(1), pp.79-82 https://www.ajol.info/index.php/ijotafs/article/view/76008

42. Bashir, I., Adam, A.S., Yahaya, H.S., Makeri, D., Ntulume, I., Aliero, A.A., and Afolabi, R.O., 2018. Assessment of bacteriological quality of borehole water in Wamakko local government, Sokoto state, Nigeria. Novel Research in Microbiology Journal, 2(6), pp.175-184. Doi: 10.21608/NRMJ.2018.22710

\section{COPYRIGHTS}

(C)2021 The author(s). This is an open access article distributed under the terms of the Creative Commons Attribution (CC BY 4.0), which permits unrestricted use, distribution, and reproduction in any medium, as long as the original authors and source are cited. No permission is required from the authors or the publishers.

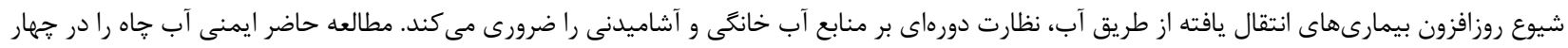

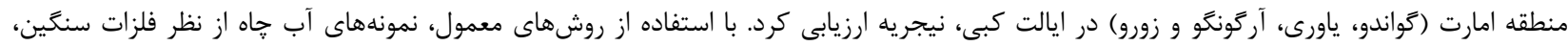

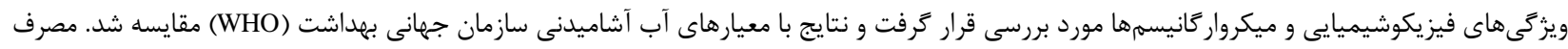

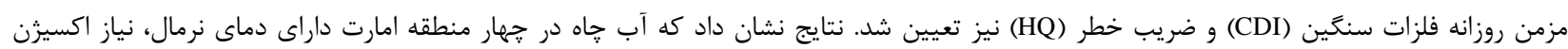

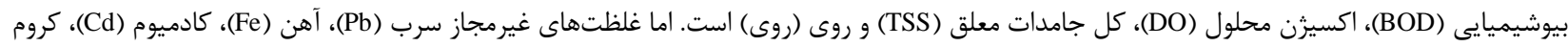

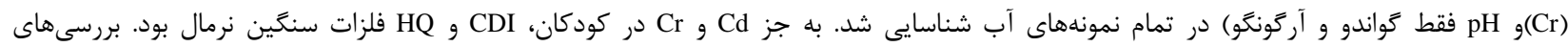

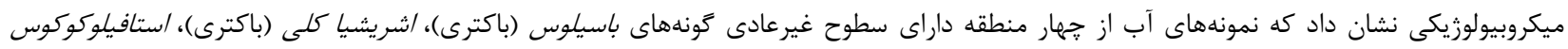

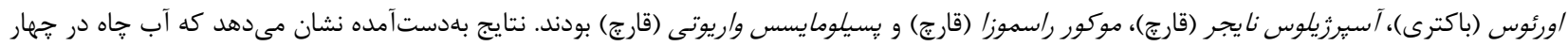

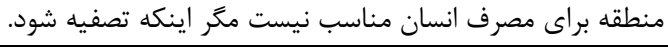

